\title{
Soil Carbon Pools in Adjacent Natural and Plantation Forests of Subtropical Australia
}

\author{
C. R. Chen, * Z. H. Xu, and N. J. Mathers
}

\begin{abstract}
ABSTRAC'T
Soil C dynamics are not only important to both productivity and sustainability of terrestrial ecosystems, but also contribute significantly to global C cycling. Adjacent matural forest (NF), and first (1R) and second rotation (2R) hoop pine (Araucaria cunninghamii Aiton ex A. Cumn.) plantations in southeast Queensland, Australia, were selected to investigate the effects of conversion of NF to hoop pine plantations and forest management (harvesting and site preparation of plantation) on the size and the nature of $\mathrm{C}$ pools in surface $(0-10 \mathrm{~cm})$ soils using chemical extraction, laboratory incubation and ${ }^{13} \mathrm{C}$ crosspolarization with magic-angle-spinning nuclear magnetic resonance spectroscopy ( ${ }^{13} \mathrm{C}$ CPMAS NMR). Conversion from NF to hoop pine plantations not only led to the reduction of soil total $\mathrm{C}$ (by $19.8 \%$ ), water-soluble organic C (WSOC) (by 17.7\%), CaCl - extractable organic C (by $38.8 \%$ ), and hot water-extractable organic C (HWEOC) (by $30.9 \%$ ) and bioavailability of soil C (as determined by $\mathrm{CO}_{2}$ evolved in the incubation), but also to a change in chemical composition of soil C with lower O-alkyl C and higher alkyl C under the $1 \mathrm{R}$ plantation compared with NI. Harvesting and site preparation did not significantly affect total soil $\mathrm{C}$ and most labile $\mathrm{C}$ pools (except for a decrease in WSOC), but led to a lower signal intensity in the alkyl $\mathrm{C}$ spectral region and a decreased alkyl $\mathrm{C} / 0$-alkyl $\mathrm{C}(\mathrm{A} / \mathrm{O}-\mathrm{A})$ ratio in the soil moler the $2 R$ compared with the $1 R$ plantation. The shifts in the amount and nafure of soil $C$ following forest conversion may be attributed to changes in litter inputs, microbial diversity and activity, and the disturbance of soil during harvesting and site preparation.
\end{abstract}

$\mathrm{L}$ ND-USL: CHANGis or shifts in cultivation can affect soil organic matter (Howard et al., 1998; Chen et al., 2000; Mao et al., 2002; Schroth et al., 2002). Davis and Condron $(20(02)$ reviewed a series of paired-site studies in New Zealand and suggested that conversion from grassland to plantation forest decreased organic C by $9.5 \%$ in the upper layer (mainly the $0-$ to $10-\mathrm{cm}$ soil) in the short term $(<20 \mathrm{yr})$, but that accumulation of organic $\mathrm{C}$ in the forest floor exceeded the loss of $\mathrm{C}$ in the mineral soils. Smith et al. (2002) reported that, in Brazil, conversion from native Amazonian forest to plantation forests also altered the quantity of soil $\mathrm{C}$, with an increase in surface soil C under Euxylophora paraensis Hub. plantation and decreases under Pinus carihaea var. honduensis Barrett and Gollari, and Carapa guiunensis Aubl. plantations. Howard et al. (1998), Quideau el al. (2000), and Paul et al. (2002) also suggested that tree species had different impacts on soil $\mathrm{C}$ pools and dynamics. Furthermore, land-use change can also alter the chemical nature of soil organic C (Golchin

C.R. Chen and N.J. Mathers, Cooperative Research Centre (CRC) for Sustainable Production forestry, Faculty of Environmental Sciences, Grillith Iniversity, Nathan, Ouecnsland 4111, Australia: 7..H. Xu Ouecusland Forestry Rescarch Institute and the CRC, P.O. Box 631 Indooroopilly, Quecnsland 4068, Australia. Received 6 Nov. 2002 *Corresponding author (chengrong.chen(omailbox.gu.edu.au).

Published in Soil Sci. Soc. Am. J. 68:282-291 (2004)

(c) Soil Science Society of America

677 S. Segoc Rd., Madison, WI 53711 USA et al., 1997; Howard et al., 1998; Quideau et al., 2000). For example, Golchin ct al. (1997) found that the soil organic matter developed under the grass Miscanthus sinensis in the Andosol was more aromatic in nature than that under adjacent forest, and invasion of grassland by forest resulted in a decrease in C aromaticity and an increase in alkyl C content of soil. More recently, a direct link between tree species and the composition of soil organic matter has been revealed (Quideau et al., 2001). However, Beets et al. (2002) reported that the impacts of management practices (c.g., forest harvesting) on soil C was unclear, while Johnson and Curt is (2001) reported that tree harvesting had little or no effects on soil $\mathrm{C}$ content.

Numerous methods, including chemical extraction, isotopic techniques, and various spectroscopic analyses, have been used to characterize soil C pools and dynamics (Kögel-Knabner, 2000); Chodak et al., 2002; Magid et al., 2002; Mathers et al., 2000); Zaccheo et al., 2002). Water and dilute salt solution (e.g., $\mathrm{CaCl}_{2}$ and $\mathrm{K}_{2} \mathrm{SO}_{4}$ ) extract soil organic $\mathrm{C}$ representing relatively labile organic C pools in soil (e.g., Nishiyama et al., 2001). The high turnover rate of soil labile C pools indicates their significance in $\mathrm{C}$ and nutrient cycling in terrestrial ecosystems (Hu et al., 1997). In recent years, nondestructive spectroscopic methods, such as ${ }^{13} \mathrm{C}$ solid-state CPMAS NMR spectroscopy and pyrolysis-ficld ionization mass spectrometry (Py-FIMS) techniques, have been increasingly used to characterize the chemical composition of soil $\mathrm{C}$ without extraction and fractionation (Preston, 1996; Schnitzer, 2001). The application of CPMAS and high power decoupling techniques in solid-state ${ }^{13} \mathrm{C}$ NMR increases the ${ }^{13} \mathrm{C}$ signal and the signal/noise ratio and decreases line broadening (Wilson, 1987; Mathers et al., 2000; Quideau et al., 2001). The pretreatment of forest soil samples with $2 \% \mathrm{HF}(\mathrm{v} / \mathrm{v})$ has been found to remove interfering paramagnetic materials (c.g., Fo and $\mathrm{Mn}$ ) and also improve the quality of ${ }^{13} \mathrm{C}$ CPMAS NMR spectra by reducing the signal/noise ratio (Mathcrs et al., 2002).

Hoop pine is a native rainforest species of southeast Queensland (SEQ), Australia. The majority of the current hoop pine plantations (approximately 50000 ha) in SEQ was established on the previous natural forestland. Little information is available on the impacts of conversion from NF to hoop pine plantations on soil organic $\mathrm{C}$ and associated nutricnts. For this study, it was hypothesized that conversion of NF to hoop pine plantations and management practice (c.g., harvesting and site prep-

Abbreviations: IR, first rolation; $2 \mathrm{R}$, second rolation; $\mathrm{A} / \mathrm{O}-\mathrm{A}$, alky CO-alkyl ratio; bioavail-C, bioavailable soil organic carbon; CPMAS NMR, cross polarization with magie-angle-spinning nuclear magnetic resonance; HWEOC, hot water-extractable organic $\mathrm{C} ; \mathrm{NF}$, natural Forest: SEO, southeast Quecnsland; SSB, spinning sidebands; WSOC water-soluble organic $C$. 
aration) can alter the size and the chemical and biological nature of soil C pools. Adjacent NF and $1 \mathrm{R}$ and $2 \mathrm{R}$ hoop pine plantations were selected and a combination of chemical, biological, and NMR methods was applied to test this hypothesis.

\section{MATERIALS AND METHODS}

\section{Site Description and Soil Sampling}

The site is located within the Yarraman State Forest, SEQ, Australia $\left(26^{\circ} 52^{\prime} \mathrm{S}, 151^{\circ} 51^{\prime} \mathrm{E}\right.$ ), lying in the upper catchment of the Brisbane River. The soil is a Typic Durustalf (Soil Survey Staff, 1999). Altitude at the site is $428 \mathrm{~m}$ above sea level. Annual rainfall varies from 433 to $1110 \mathrm{~mm}$, with an average of $791 \mathrm{~mm}$. Winter temperatures range from 4 to $20)^{\circ} \mathrm{C}$, and summer temperatures from 17 to $29^{\circ} \mathrm{C}$. The NF and $1 \mathrm{R}$, and $2 \mathrm{R}$ hoop pine plantation sites are adjacent 10 each other on the same position of the slope of approximately 2 to $3^{\circ}$. The NF site is classified as a mixed rainforest/scrub and dominated by bunya pine (Araucaria bidwilli Hook.), yellowwood (Terminalia oblongata $F$. Muell. subsp. oblongata), crows ash (Pentaceras australis R.B.), and lignum-vitac (Premna lignum-vitae), with cmergent hoop pine (Araucaria cunninghamii Aiton ex A. Cunn.). Before plantation of $1 \mathrm{R}$ hoop pine, larger trees of natural forests were logged using bullock teams and a small dozer, and the understory scrub and the residues were brushed off to a height no $>15 \mathrm{~cm}$ to be scattered evenly across the site, and were burnt when dry. It should be noted that a certain extent of disturbance might occur during site preparation for $\mathrm{IR}$ hoop pine plantation. The IR hoop pine plantation was cstablished in 1949 at approximatcly 1540 stems ha ${ }^{-1}$ by hand planting and then thinned to a final stocking of 430 stems ha I. The $2 \mathrm{R}$ hoop pine site was planted in November 2000 after the elearcut harvest of part of the $1 \mathrm{R}$ hoop pine plantation using Timco harvester in September 1999. For the site preparation, a D5M dozer (Catapillar Inc., Peoria, IL) was used for pushing row lines through the clearfall residues at $6 \mathrm{~m}$ intervals, the row lines were then cultivated prior to planting. The stocking density at the $2 \mathrm{R}$ hoop pine site was approximately 620 stems ha ' when the soil was sampled. The $1 \mathrm{R}$ hoop pine was approximately $51 \mathrm{yr}$ old and the $2 \mathrm{R}$ hoop pine $2 \mathrm{yr}$ old when soil was sampled.

Each (about 30 by $100 \mathrm{~m}$ ) of the rescarch areas under adjacent $N F$, and $1 R$ and $2 R$ hoop pine plantations was divided into five subplots for soil sampling. A total of 25 soil cores $(0-10 \mathrm{~cm})$ were randomly collected with an auger of approximately $7.5 \mathrm{~cm}$ in diameter from each subplot and bulked (well mixed) in October 2001. In the $2 \mathrm{R}$ hoop pine plantation, the soil was sampled from areas between the windrows of postharvest residues. Ficld-moist soil samples were sieved $(<2 \mathrm{~mm})$ and stored at $4^{\circ} \mathrm{C}$ (approximately $\left.2 \mathrm{wk}\right)$ until analysis of WSOC and its fulvic and humic acid C fractions, and chloroform-released $C$. A subsample of each soil was air-dried for chemical analysis and incubation.

\section{Chemical Analysis of Soil Labile Carbon}

Water-soluble organic $\mathrm{C}$ was extracted by shaking $50 \mathrm{~g}$ (oven-dried equivalent) of moist soil at a soil/water ratio of $1: 3$ on an end-to-end shaker at $4^{\circ} \mathrm{C}$ for $16 \mathrm{~h}$. The mixture was then spun at $6500 \times g$ for $1 \mathrm{~h}$ and filtered through a Whatman GF/F filter (combusted at $450^{\circ} \mathrm{C}, 4 \mathrm{~h}$ ) (Boyer and Groffman, 1996). The C in the extracts was determined by a SHIMADZU TOC-VCPH analyzer (Shimadzu, Kyoto, Japan) using high temperature $\left(680^{\circ} \mathrm{C}\right)$. To fractionate WSOC, $20 \mathrm{~mL}$ of each extract was acidified to $\mathrm{pH} 2$ with three drops of $10 \% \mathrm{HCl}$ $(v / v)$; the humic acid fraction (WSOC-HAC) was precipitated at $4^{\circ} \mathrm{C}$ overnight and centrifuged at $750 \times g$ for $10 \mathrm{~min}$. The supernatant (acid-soluble fraction) was removed for analysis of dissolved organic $\mathrm{C}$ (fulvic acid C, WSOC-FAC). This C fraction contains fulvic acid, some carbohydrates, and amino acids (Boyer and Groffman, 1996). The WSOC-HAC in the water extract was estimated by calculating the difference between WSOC and WSOC-FAC.

Hot water-extractable organic $C$ was measured by the method described by Sparling et al. (1998). In briel, $4.0 \mathrm{~g}$ (oven-dry equivalent) of air-dried soil was incubated with $20 \mathrm{~mL}$ of water in a capped test-tube at $70^{\circ} \mathrm{C}$ for $18 \mathrm{~h}$, and test-tubes were then shaken on an end-to-end shaker for 5 min, and liltered through a Whatman 42 paper (Whatman Ltd., Maidstone, UK), followed by a $(0.45-\mu$ m filter membrane. The organic $\mathrm{C}$ concentration in the filtrate was determined using a SHIMADZU TOC-VCPH analyzer.

Calcium chloride extractable organic $\mathrm{C}$ was measured by extracting $10 \mathrm{~g}$ (oven-dried equivalent) air-dried soil with $25 \mathrm{~mL}$ of $10 \mathrm{mMCaCl}$ on an end-10-end shaker for $30 \mathrm{~min}$ and the organic C extracted was determined using a SHIMADZU TOC-VCPH analyzer.

\section{Biologically Available Soil Carbon - Incubation Method}

Biologically available soil organic C (bioavail-C) was determined using the incubation method as described by Chen et al. $(2000)$. In brief, $15 \mathrm{~g}$ of air--dricd soil was adjusted to $60 \%$ of the field capacity and incubated acrobically in a l-L sealed glass jar at $22^{\circ} \mathrm{C}$, and $\mathrm{CO}$, evolved from soil was trapped in $0.1 \mathrm{M} \mathrm{NaOH}$ and measured by acid titration $(0.1 \mathrm{M} \mathrm{I} \mathrm{ICl})$ after $1,3,7,14,21,28$, and $35 \mathrm{~d}$. The bioavail-C was estimated by calculating the cumulative production of $\mathrm{CO}_{2}$ from soil cluring the $35-d$ incubation.

\section{Chloroform-Released Carbon}

Chloroform-released organic C (CHCliseleased ()) was measured by the fumigation-extraction method (Vance et al., 1987). Chloroform-released C was calculated as the difference in organic $C$ between the fumigated and the unlumigated samples. Microbial biomass ( was not calculated due to the uncertainty in the conversion factor, Ec (Ross and Sparling, 1993). Chlorolorm-released C fraction was used to represent the microbial component of soil organic $C$.

\section{Hydrofluoric Acid Pretreatment of Soil Samples and Carbon-13 Solid State NMR Spectroscopy}

Pretreatment of soil samples with $\mathrm{HF}$ before solid-state " $\mathrm{C}$ CPMAS NMR analysis removes a substantial amount of $\mathrm{FC}^{3}$ and $\mathrm{Mn}^{2}$ in soil and concentrates the organic matter of a whole soil sample, improving the signal/noise ratio (Mathers et al., 2002; Schmidt et al., 1997; Skjemstad ct al., 1994). Consequently, after $\mathrm{HF}$ pretreatment, fewer seans are required for better resolution of spectra and solid-state C CPMAS NMR analysis times can be reduced without a reduction in spectral quality. In this study, all soil samples for NMR analysis were pretreated with $2 \% \mathrm{HF}$ according to the method described by Skjemstad et al. (1994) and modified by Mathers et al. (2002).

Solid-state ${ }^{1 . C}$ CPMAS NMR spectral of the HF-treated soils were obtained at a frequency of $100.6 \mathrm{MH}$ on a Varian Unity lnova40() spectrometer (Varian Inc., Palo Alto, (A). Samples were packed in a silicon nitride rotor (optical density $=7 \mathrm{~mm}$ ) and spun at $5 \mathrm{kl} \%$ at the magic angle. Single contact times of $2 \mathrm{~ms}$ were applied, with an acquisition time of $14 \mathrm{~ms}$, and a recycle delay of $1.5 \mathrm{~s}$. Approximately 6000 
Table 1. Basic chemical and physical properties in soils $(0-10 \mathrm{~cm})$ under adjacent natural forest (NF) and hoop pine plantations (first rotation, $1 \mathbb{R}$, and second rotation, $2 \mathbb{R}) . \dagger$

\begin{tabular}{|c|c|c|c|c|c|c|c|c|c|}
\hline $\begin{array}{l}\text { Vegetation } \\
\text { type }\end{array}$ & pH & Total C & Total $\mathrm{N}$ & $\begin{array}{l}\mathrm{C} / \mathrm{N} \\
\text { ratio }\end{array}$ & $\begin{array}{c}\text { Soil } \\
\text { moisture }\end{array}$ & $\begin{array}{c}\text { Bulk } \\
\text { density }\end{array}$ & Sand & Silt & Clay \\
\hline & & \multicolumn{2}{|c|}{$\longrightarrow \mathrm{g} \mathrm{kg}^{-1} \longrightarrow$} & & $\mathrm{g} \mathrm{kg}^{-1}$ & $\mathbf{M g} \mathbf{m}^{-3}$ & 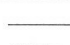 & $\mathrm{g} \mathrm{kg}^{-1}$ & - \\
\hline NF & $4.7 b$ & $79.6 a$ & $6.70 \mathrm{a}$ & $11.9 \mathrm{~b}$ & $250 \mathrm{~b}$ & $0.688 \mathrm{a}$ & $327 a$ & $189 \mathrm{c}$ & $484 a$ \\
\hline $1 \mathrm{R}$ & $6.0 \mathrm{a}$ & $63.8 \mathrm{~b}$ & $4.86 c$ & 13.1a & $262 b$ & $0.726 a$ & $334 a$ & $306 a$ & $360 \mathrm{a}$ \\
\hline $2 \mathbf{R}$ & $5.6 a$ & $64.0 \mathrm{~b}$ & $5.36 \mathrm{~b}$ & $11.9 \mathrm{~b}$ & $361 \mathrm{a}$ & $0.736 a$ & $280 a$ & $271 b$ & $449 \mathrm{a}$ \\
\hline
\end{tabular}

$\dagger$ Data in a column are means $(n=5)$. Means within a column followed by the same letter are not different at the $5 \%$ level of significance.

transients were collected for all samples and a Lorentzian lino broadening function of $150 \mathrm{H} \%$ was applied to all spectra. Chemical shift values were referenced externally to hexamethylbenzene at $132.1 \mathrm{ppm}$, which is equivalent to tetramethylsilane at 0 ppm.

The solid-state ${ }^{13} \mathrm{C}$ CPMAS NMR spectra were divided into the four common chemical shift regions: alkyl C (0-50 ppm), O-alkyl C. (50-110 ppm), aromatic and olefinic C (110-160 $\mathrm{ppm}$ ) and carboxyl C(160-210 ppm), and the relative intensity for each region was determined by integration using the Varian NMR software package (Version 6.1c, Varian Inc., Palo Alto, CA). In some instances it was necessary to further divide some chemical shift regions, these were: O-alkyl C into methoxyl C (50-60 ppm), carbohydrate C (60)-95 ppm), and diO-alkyl C (95-110 ppm); aromatic C into aryl C (110-145 ppm) and phenolic $C(145-160 \mathrm{ppm})$; and carboxyl Cinto carboxylic amide/ester $C(160-190 \mathrm{ppm})$ and ketone/aldehyde $C(190-210$ ppm). No attempt was made to remove spinning sidebands (SSB) during acquisition. However, the carboxyl and aromatic C spectral regions produce SSB, which appear at approximately 223 and $183 \mathrm{ppm}$, respectively. Because SSB of equal intensity are produced on either side of the originating center band, the visible carboxylic/amide/ester and ketone/aldehyde SSB in the carboxyl region were integrated, and the aromatic and carboxyl C spectral regions were corrected for the presence of these SSB. Spinning sidebands originating from the aryl signal at $133 \mathrm{ppm}$ would appear at 183 and $83 \mathrm{ppm}$, but both are within other chemical shift regions, making it difficult to correct for these SSB. The aryl C region will also contain SSB originating from the carboxyl C peak (174 ppm) at 124 ppm that ean be corrected for, but that would make the intensity of the aryl C peak at $133 \mathrm{ppm}$ appear greater than it actually is. This would have implications for the SSB from the aryl peak (at 183 and 83 ppm) as they should not be larger in intensity than the centered band peak (133 ppm) itself.

The $N / O-A$ ratio, the ratio of alkyl C region intensity $(0-50$ ppm) to $($-alkyl C region intensity $(50-110 \mathrm{ppm})$, which has been used as an index of the extent of decomposition (Baldock and Preston, 1995; Baldock et al., 1992) or of substrate quality for microbes (Webster et al., 2000), was also calculated in this study as an indicator of the quality of soil organic $C$.

\section{Statistical Analysis}

Onc-way ANOVA was carricd out for all data on soil propcrties in Statistix for Window version 2.2 (Analytical Software,
Tallahassee, FL). The normality of all data were checked and met before ANOVA, while we acknowledge that the limita tion of this experimental study, as many other paired-site studies, was pseudo-replication. Least significant difference (LSD, $P<0.05$ ) was used to separate the means when differences were significant. Pearson linear correlations between $\mathrm{C}$ pools were also conducted in Statistix for Windows version 2.2.

\section{RESULTS}

Table 1 shows some soil basic properties under the adjacent NF and $1 \mathrm{R}$ and $2 \mathrm{R}$ hoop pine plantations. Soil total C ranged from 72.3 to $82.9 \mathrm{~g} \mathrm{~kg}^{-1}$ under $\mathrm{NF}$, being significantly higher than under the $1 \mathrm{R}\left(56.4-67.0 \mathrm{~g} \mathrm{~kg}{ }^{1}\right)$ and the $2 \mathrm{R}\left(57.8-71.4 \mathrm{~g} \mathrm{~kg}^{-1}\right)$ plantations. Soil total $\mathrm{N}$ was also higher under NF compared with the $1 \mathrm{R}$ and $2 \mathrm{R}$ plantations, but soil pH was lower under NF than under $1 \mathrm{R}$ and $2 \mathrm{R}$ plantations. However, there were no significant differences in soil $\mathrm{pH}$ and total $\mathrm{C}$ between $1 \mathrm{R}$ and $2 \mathrm{R}$ plantations. Total $\mathrm{N}$ was significantly higher in soil under the $2 \mathrm{R}$ plantation than under the $1 \mathrm{R}$ plantation. Soil $\mathrm{C} / \mathrm{N}$ ratio was lower under $\mathrm{NF}$ and the $2 \mathrm{R}$ plantation than under the IR plantation (Table 1). Soil moisture content was significantly higher under the $2 \mathrm{R}$ plantation than under NF or the $1 \mathrm{R}$ plantation. There were no significant differences in bulk density, sand, or clay contents among three sites, but silt contents in soil under the $1 \mathrm{R}$ plantation were higher than under NF or the $2 \mathrm{R}$ plantation.

\section{Chemical Extractable Soil Organic Carbon}

Water-soluble organic C ranged from 24.1 to $53.7 \mathrm{mg}$ $\mathrm{kg}^{-1}$ among soils under $\mathrm{NF}$ and $1 \mathrm{R}$ and $2 \mathrm{R}$ plantations. Levels of WSOC under NI: were highest among three sites and significantly higher in the soil under the $1 \mathrm{R}$ than the 2R plantation (Table 2). The WSOC only comprised 0.039 to $0.074 \%$ of total $\mathrm{C}$ among three sites while the ratios of WSOC/IC were greater under NF and $1 \mathrm{R}$ plantation than under the $2 \mathrm{R}$ plantation (Table 2). The WSOC-FAC in WSOC was dominant (47.2$84.6 \%$ of WSOC), compared with WSOC-HAC (15.4$52.8 \%$ ) (Table 2). Levels of WSOC-FAC fractions were

Table 2. Water-soluble organic $\mathbb{C}$ (WSOC) and fulvic acid $\mathbb{C}$ (WSOC-FAC) and humic acid $\mathbb{C}$ factions (WSOC-HAC) in adjacent soils $(0-10 \mathrm{~cm})$ under natural forest $(\mathrm{NF})$ and hoop pine plantations (first rotation, $1 \mathbb{R}$, and second rotation, $2 \mathbb{R}) . \dagger$

\begin{tabular}{|c|c|c|c|c|}
\hline Vegetation type & WSOC & WSOC-FAC & WSOC-HAC & WSOC/TC \\
\hline & & $\mathrm{mg} \mathrm{kg}^{-1}$ & 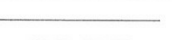 & $\%$ \\
\hline NF & $48.6(5.6) \mathrm{a}$ & $37.7(5.5) a$ & $10.9(3.1) \mathrm{a}$ & $0.061(0.005) \mathrm{a}$ \\
\hline $1 \mathrm{R}$ & $40.0(7.1) b$ & $27.3(2.3) \mathrm{b}$ & $12.6(1.2) \mathrm{a}$ & $0.063(0.009) \mathrm{a}$ \\
\hline $2 \mathbb{R}$ & $31.7(4.9) \mathrm{c}$ & $20.5(6.1) \mathrm{b}$ & $11.2(2.0) \mathrm{a}$ & $0.050(0.008) b$ \\
\hline
\end{tabular}

$\uparrow$ Data in a column are means $(n=5)$; data in parentheses are standard errors of the means. Means within a column followed by the same letter are not different at the $5 \%$ level of significance.

The ratio of WSOC to total $\mathrm{C}$ in soil. 

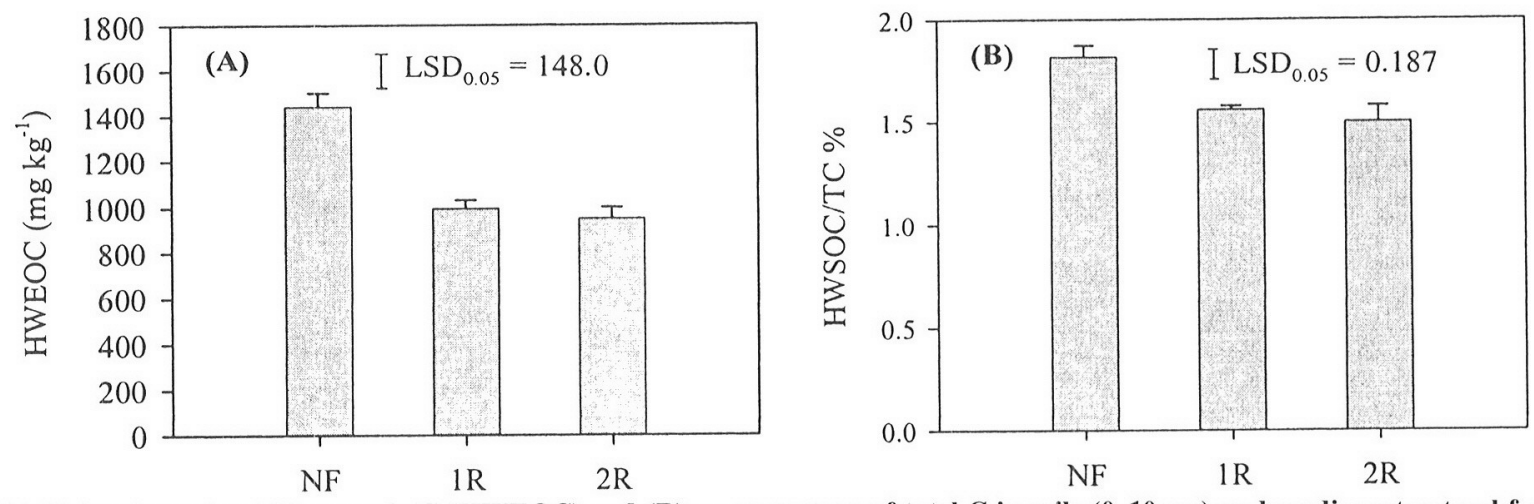

Fig. 1. (A) Hot water-extractable organic $C$ (HWEOC) and (B) as percentage of total $C$ in soils $(0-10 \mathrm{~cm})$ under adjacent natural forest (NF) and first (1/R) and second $(2 \mathbb{R})$ rotation hoop pine plantations at Yarraman State Forest, southeast Queensland.

significantly greater under NF than under either $1 \mathrm{R}$ or $2 \mathrm{R}$ plantations (Table 2), but there were no significant differences in soil WSOC-HAC fractions amongst the three sites.

Hot water-extractable organic $\mathrm{C}$ ranged from 1265 to $1600 \mathrm{mg} \mathrm{kg} \mathrm{kg}^{-1}$ in soil under NF. This was significantly higher than under the $1 \mathrm{R}\left(871-1072 \mathrm{mg} \mathrm{kg}^{-1}\right)$ and the $2 \mathrm{R}$ (808-1113 mg kg ') plantations (Fig. 1). The HWEOC comprised 1.7 to $2.1 \%$ of total $\mathrm{C}$ in soil under NF, which was significantly greater than under the $1 \mathrm{R}(1.5$ to $1.7 \%)$ and the $2 \mathrm{R}$ (1.3 to $1.7 \%$ ) plantations (Fig. 1). There were no significant differences in soil HWEOC between the $1 \mathrm{R}$ and $2 \mathrm{R}$ plantations (Fig. 1). The $\mathrm{CaCl}_{2}$ extractable organic $\mathrm{C}$ ranged from 174 to $218 \mathrm{mg} \mathrm{kg}^{-1}$ in soil under NF. This was significantly greater than under the 1R (69-163 $\left.\mathrm{mg} \mathrm{kg}^{-1}\right)$ and the 2R (72-182 $\left.\mathrm{mg} \mathrm{kg}^{-1}\right)$ plantations (Fig. 2). There were no significant differences in $\mathrm{CaCl}_{2}$ extractable organic $\mathrm{C}$ between the $1 \mathrm{R}$ and $2 \mathrm{R}$ plantations.

\section{Chloroform-released Carbon and Bioavailable Soil Organic Carbon}

Chloroform-released $\mathrm{C}$ appears to be greater in soils under NF (247-458 $\mathrm{mg} \mathrm{kg}^{-1}$ ) and the 2R plantation (310-405 $\mathrm{mg} \mathrm{kg}^{-1}$ ) compared with the $1 \mathrm{R}$ plantation $\left(152-412 \mathrm{mg} \mathrm{kg}{ }^{-1}\right)$, although the differences among NF, $1 \mathrm{R}$, and $2 \mathrm{R}$ hoop pine plantations were not statistically

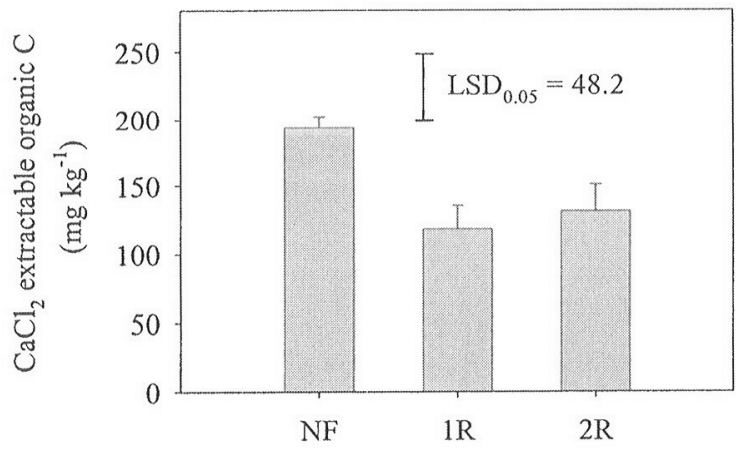

Fig. 2. The $\mathrm{CaCl}_{2}$-extractable organic $\mathrm{C}$ in soils $(0-10 \mathrm{~cm})$ under adjacent natural forest $(\mathrm{NF})$ and first $(1 \mathrm{R})$ and second $(2 \mathrm{R})$ rotation hoop pine plantations at Yarraman State Forest, southeast Queensland. significant (Fig. 3). The bioavail-C was significantly and consistently greater in soil under NF (1149-1362 mg $\left.\mathrm{kg}^{-1}\right)$ than under the $1 \mathrm{R}\left(718-829 \mathrm{mg} \mathrm{kg}{ }^{-1}\right)$ and $2 \mathrm{R}$ (613-746 $\mathrm{mg} \mathrm{kg}^{-1}$ ) plantations (Fig. 4). However, there were no significant differences in bioavail-C between soils under the $1 \mathrm{R}$ and $2 \mathrm{R}$ plantations (Fig. 4).

\section{Carbon-13 CPMAS NMR Spectra}

It has been suggested that the information obtained from ${ }^{13} \mathrm{C}$ CPMAS NMR spectroscopy is semi-quantitative duc to some technical reasons (e.g., different efficiency of the cross-polarization for different $\mathrm{C}$ forms, SSB and so on) (Preston, 1996, 2001; Mathers et al., 2000). However, ${ }^{13} \mathrm{C}$ CPMAS NMR spectra can be compared for soil samples of similar origin run under identical conditions (Preston, 1996; Quideau ct al., 2001). More recently, Conte et al. (20)2) revealed that C measured by ${ }^{13} \mathrm{C}$ CPMAS NMR spectroscopy provided a quantitative representation of the whole $\mathrm{C}$ content in humic substance. The relative intensitics of $\mathrm{C}$ functional groups in the HF-treated soils under adjacent NF and $1 \mathrm{R}$ and $2 \mathrm{R}$ hoop pine plantations are shown in Table 3. Representative ${ }^{1 .} \mathrm{C}$ NMR spectra are shown in Fig. 5. Across all soil samples among three sites, the intensity in the alkyl C spectral region was highest $(32.3-42.9 \%$ of total intensity), followed by O-alkyl C (24.0-31.0\%) and carboxyl $C$ (the sum of carboxylic/amide/ester $C$

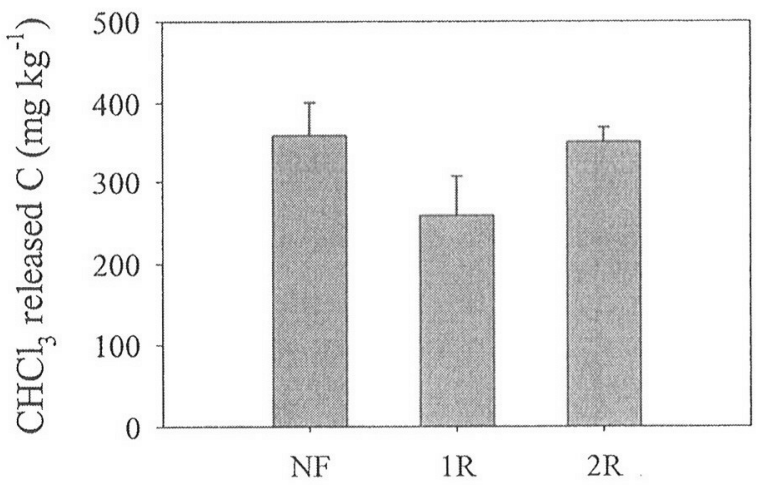

Fig. 3. The $\mathrm{CHCl}_{3}-$ released organic $\mathrm{C}$ in soils $(0-10 \mathrm{~cm})$ under adjacent natural forest (NF) and first (1R) and second (2R) rotation hoop pine plantations at Yarraman State Forest, southeast Queensland (spinning side band, ssb). 


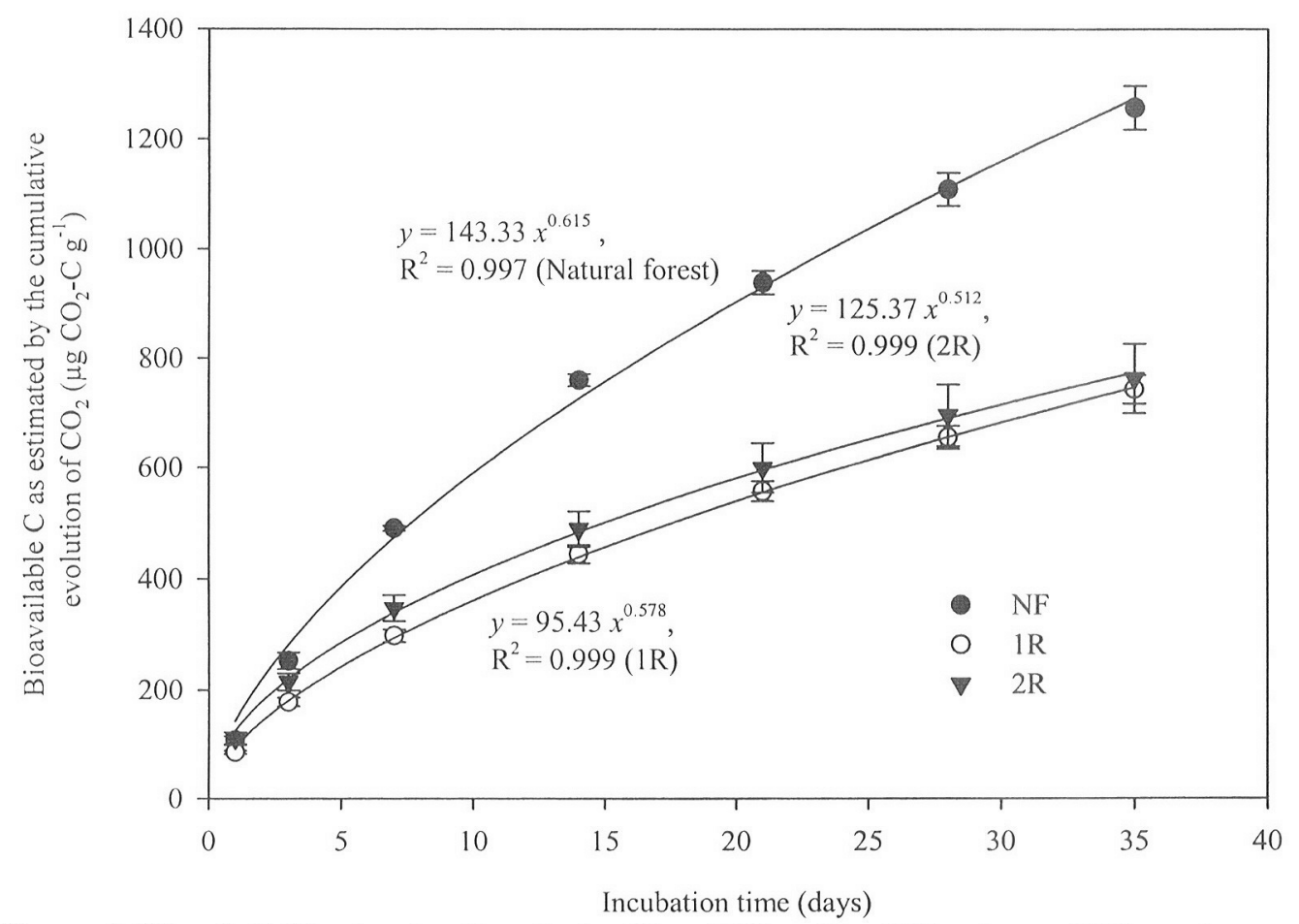

Fig. 4. Bioavailable organic $\mathrm{C}$ in soils $(0-10 \mathrm{~cm})$ under adjacent natural forest (NF) and first (1R) and second (2R) rotation hoop pine plantations at Yarraman State Forest, southeast Queensland.

and ketone/aldehyde C, 25.5-36.6\%), and the lowest intensity was found in the aromatic region (the sum of aryl (Cand phenolic C, 3.2-7.6\%). The signal intensity in the alkyl C spectral region $(0-50 \mathrm{ppm})$ was significantly higher in soil under the $1 \mathrm{R}$ hoop pine plantation than under $\mathrm{NF}$ or the $2 \mathrm{R}$ plantation, while there were no significant differences observed in this spectral region between the NF and the $2 \mathrm{R}$ plantation (Table 3 and Fig. 5). There was a significantly higher intensity in the ()-alkyl ( spectral region (50-110 ppm) in soil under the NF than under the IR plantation; there was no significant difference in the intensity of $\mathrm{O}$-alkyl $\mathrm{C}$ spectral region between $N F$ and the $2 \mathrm{R}$ plantation nor between the $1 \mathrm{R}$ and $2 \mathrm{R}$ plantations. When the O-alkyl $\mathrm{C}$ region was divided into methoxyl $(50-60 \mathrm{ppm})$, carbohydrate (60-95 ppm) and di-O-alkyl C (90-110 ppm), the trend in intensity of the carbohydrate $C$ region was the same as that of O-alkyl ( region. There were no significant dilferenees in the methoxyl and di-O-alkyl C spectral regions also among three sites. There was no significant difference in the aromatic C region (including both aryl $\mathrm{C}$ and phenolic $\mathrm{C}$ ) among the soils under the NF and $I R$ and $2 R$ hoop pine plantations. The intensity of the carboxyl C region was greater in soil under the $2 \mathrm{R}$ plantation than under $\mathrm{NF}$ or the $1 \mathrm{R}$ plantation. There were no significant differences in ketone/aldehyde $\mathrm{C}$ region among three sites. However, the $\mathrm{A} / \mathrm{O}-\mathrm{A}$ ratio was higher in soil under the $1 \mathrm{R}$ plantation compared with $\mathrm{NF}$ and the $2 \mathrm{R}$ plantation.

\section{Relationships between the Soil Carbon Pools}

Pearson correlation analysis showed that $O$-alkyl $\mathrm{C}$ was significantly correlated with $\mathrm{CaCl_{2 }}$ organic-extractable $\mathrm{C}(r=0.681, P<0.01)$. The $\mathrm{CHCl}_{3}-$ released $\mathrm{C}$ was positively correlated with $\mathrm{CaCl}_{2}$ extractable organic $\mathrm{C}(r=0.672, P<0.01)$ and with 0 -alkyl $\mathrm{C}(r=0.626$, $P<0.05)$ but negatively correlated with alkyl $\mathrm{C}(r$ $-0.634, P<0.05$ ) (Fig. 6A). As expected, the $\mathrm{CHCl}_{3-}$ released $C$ was negatively correlated with the $\mathrm{A} / \mathrm{O}-\mathrm{A}$ ratio (Fig. 6B). Bioavailable soil organic C was positively correlated with total $\mathrm{C}(r=0.830, P<0.01), \mathrm{CaCl}_{2}$ extractable organic C $(r=0.631, P<0.05)$, WSOC $(r=$ $0.730, P<0.01)$, and WSOC-FAC $(r=0.810, P<0.01)$. Bioavailable soil organic $C$ was also highly correlated with HWEOC $(r=0.974, r<0.01)($ Fig. 7 A). In addi-

Table 3. Composition of C functional groups (\%) in HF-treated soils $(0-10 \mathrm{~cm})$ under adjacent natural forest (NF) and hoop pine plantations (first rotation, $1 \mathrm{R}$, and second rotation, $2 \mathrm{R}$ ) as characterized by ${ }^{13} \mathrm{C}$ cross-polarization magic-angle-spinning nuclear magnetic resonance (CP MAS NMR) spectroscopy. $\dagger$

\begin{tabular}{|c|c|c|c|c|c|c|c|c|c|c|}
\hline Soils & Alkyl & $\begin{array}{l}\text { Methoxyl } \\
\text { C }\end{array}$ & $\underset{\text { C }}{\text { Carbohydrate }}$ & $\begin{array}{c}\text { Di-O-alkyl } \\
\text { C }\end{array}$ & $\underset{\mathrm{C}}{\text { O-Alkyl }}$ & $\underset{\mathrm{C}}{\text { Aryl }}$ & $\begin{array}{c}\text { Phenolic } \\
\text { C }\end{array}$ & $\begin{array}{c}\text { Carboxyl } \\
\text { C }\end{array}$ & $\begin{array}{c}\text { Ketone/ } \\
\text { aldehyde C }\end{array}$ & $\begin{array}{c}\text { Alkyl C/O-alkyl } \\
\text { C ratio }\end{array}$ \\
\hline NF & $36.6(1.1) b$ & $6.0(0.4) \mathrm{a}$ & $21.1(0.2) \mathrm{a}$ & $2.3(0.4) a$ & $29.4(0.5) a$ & $5.4(0.6) a$ & $0.6(0.3) \mathrm{a}$ & $22.7(0.5) \mathrm{b}$ & $5.3(0.6) a$ & $1.3(0.1) b$ \\
\hline IR & 41.1 (1.1)a & $6.7(1.3) \mathrm{a}$ & $17.3(1.9) b$ & $2.0(0.4) a$ & $26.1(1.0) b$ & $4.5(0.9) \mathrm{a}$ & $1.0(0.8) \mathrm{a}$ & $22.2(0.6) \mathrm{b}$ & $5.1(0.7) a$ & $1.6(0.1) \mathrm{a}$ \\
\hline $2 \mathbf{R}$ & $36.0(0.8) \mathrm{b}$ & $5.8(0.4) \mathrm{a}$ & 20.1 (0.6)ab & $1.6(0.4) a$ & $27.5(0.9) \mathrm{ab}$ & $3.8(0.7) a$ & $0.3(0.5) \mathrm{a}$ & $26.0(1.6) \mathrm{a}$ & $6.4(0.8) a$ & $1.3(0.1) \mathrm{b}$ \\
\hline
\end{tabular}

$\uparrow$ Data in a column are means $(n=5)$; data in parentheses are standard errors of the means. Means within a column followed by the same letter are not different at the $5 \%$ level of significance. 

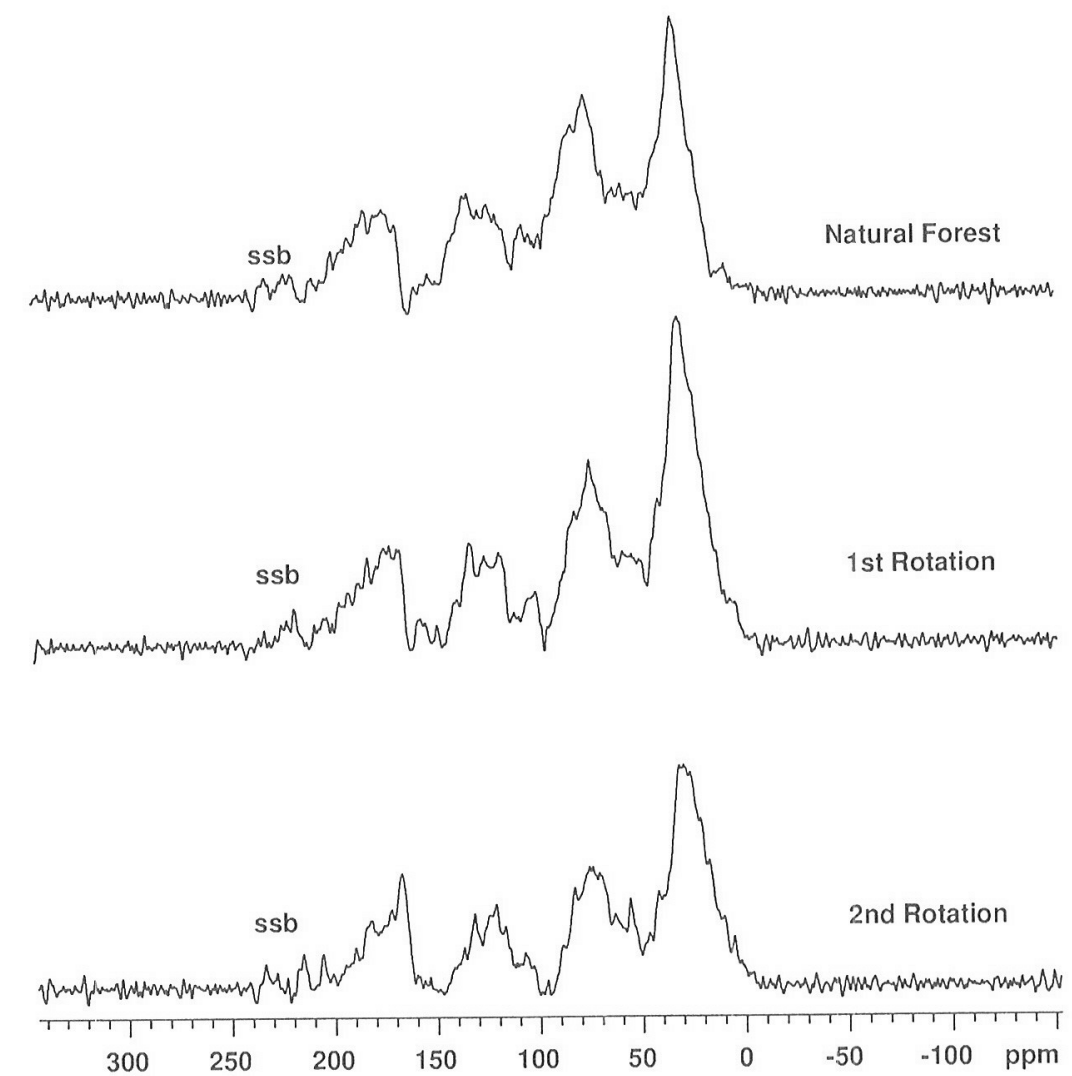

Fig. 5. Carbon-13 CPMAS NMR spectra of HF-treated soils $(0-10 \mathrm{~cm})$ under adjacent natural forest (NF) and first (1R) and second (2R) rotation hoop pine plantations at Yarraman State Forest, southeast Queensland.

tion, bioavail-C was correlated with O-alkyl $\mathrm{C}(r=$ $0.533, P<0.05)($ Fig. $7 \mathrm{~B})$.

\section{DISCUSSION}

The assumption that adjacent soils under different vegetation types were originally similar has been the basis for many paired-site studies (Chen et al., 2000), 2001; Beets et al., 2002; Priha and Smolander, 1999; Smith et al., 2002; Smolander et al., 2001). In the present study, three sites were on the same position of the slope and adjacent to each other and had similar vegetative cover (i.e., NF) prior to the establishment of the $1 R$

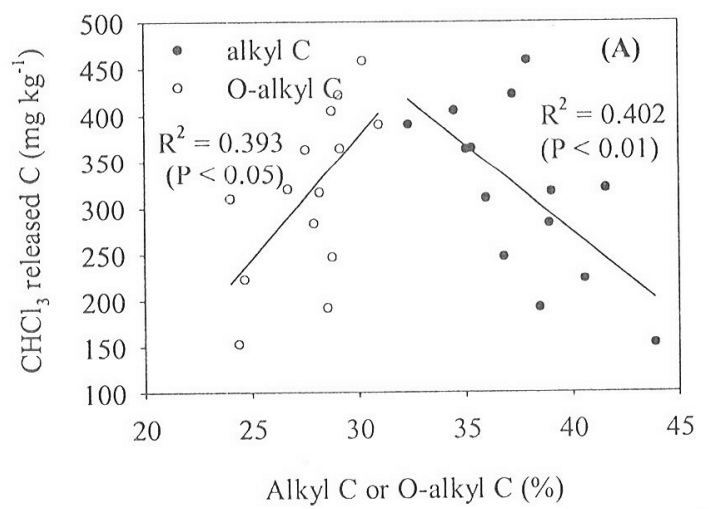

hoop pine plantation. Moreover, the underlying soils were developed from the same basaltic parent material. Thus we assume that differences in the quantity and quality of soil C among three sites were mainly due to the conversion from NF to hoop pine plantations and the impacts of forest management practices (i.e. harvesting and site preparation). The differences in soil (between $N F$ and the $1 \mathrm{R}$ plantation may rellect the effects of land-use change, including diflerent tree species and disturbance during $\mathrm{NF}^{-}$logging and sitc preparation and following forest management (e.g., thinning), while the differenee between the $1 \mathrm{R}$ and $2 \mathrm{R}$ hoop pine plantations may reflect the effects of harvesting and site prepara-

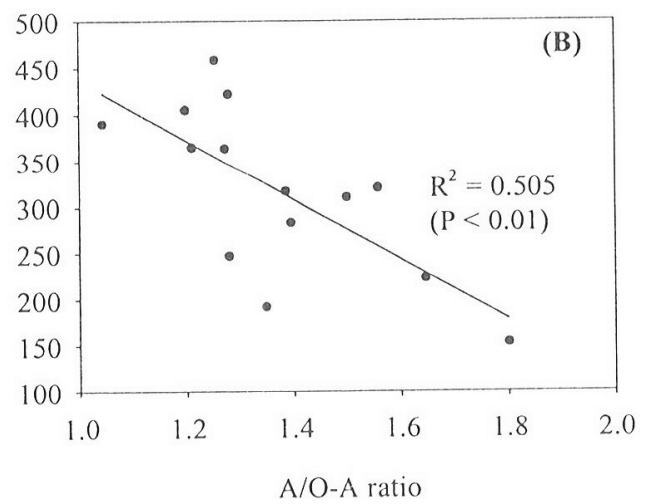

Fig. 6. Relationships between $\mathrm{CHCl}{ }_{3}$-released organic $\mathrm{C}$ and $(\mathrm{A})$ alkyl $\mathrm{C}$ or $\mathbf{O}$-alkyl $\mathbb{C}$ and (B) $\mathrm{A} / \mathrm{O}$ - $\mathrm{A}$ ratio in soils (0-10 cm) under adjacent natural forest $(\mathrm{NF})$ and first $(1 \mathbb{R})$ and second $(2 \mathbb{R})$ rotation hoop pine plantations at Yarraman State Forest, southeast Queensland. 

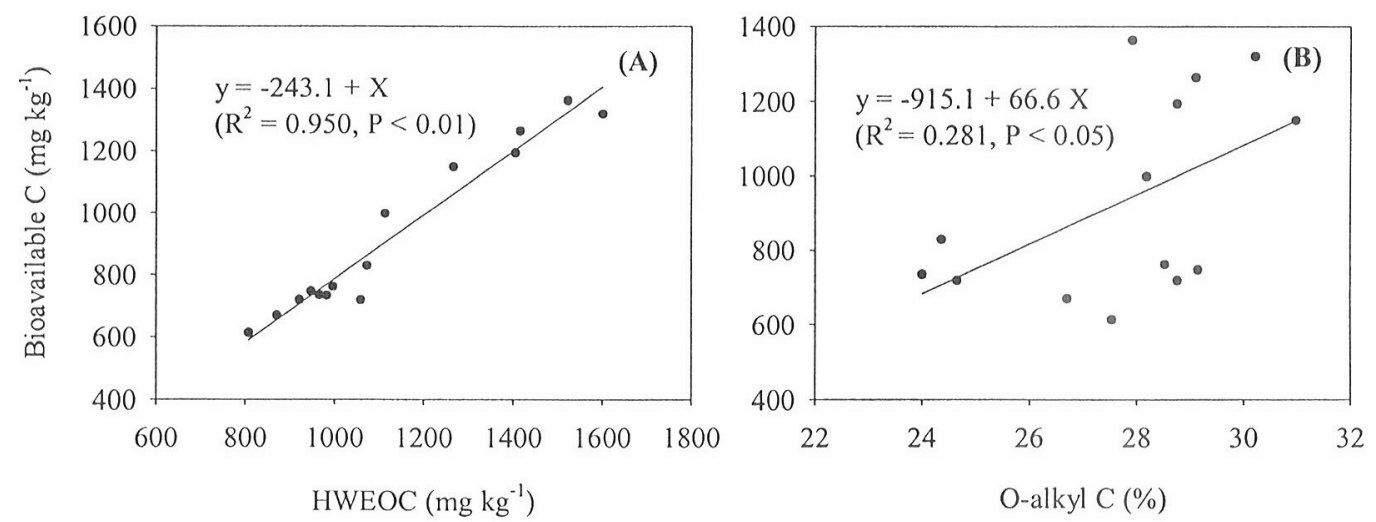

Fig. 7. Relationships between bioavailable organic $\mathbb{C}$ and $(\mathbf{A})$ hot water-soluble organic $\mathbf{C}(\mathrm{HWSOC})$ and $(\mathbb{B}) \mathbf{O}$-alkyl $\mathbb{C}$ in soils $(0-10$ cm) under adjacent natural forest (NF) and first (1R) and second (2R) hoop pine plantations at Yarraman State Forest, southeast Queensland.

tion. It is acknowledged that limitation of pseudo-replication in this study and thus the results from this study may represent a case study.

\section{Effects of Conversion of Natural Forest to Hoop Pine Plantation on Soil Organic Carbon}

Trees can alter soil properties through root-microbe interaction, root exudation, root turnover, and aboveground organic inputs. Smith et al. (2002) found that the effects of land-use change from native Amazonian forest to plantation forests in Brazil on soil $\mathrm{C}$ content were tree species-dependent. A number of studies have also indicated that tree species can have different impacts on soil C content (Howard et al., 1998; Paul et al., 2002; Pinzari et al., 1999). However, Shiels et al. (2001) found that there was no significant difference in soil C under adjacent krummholy tree species (Picea enge/mamnii krummholy and Pinus aristata krummholy. Engelm.). In the present study, soil C content under the NF was significantly higher than under the $1 R$ and $2 R$ plantations (Table 1). This may be partly attributed to differences in the amount, chemical composition, and transformation rate of organic materials derived from leaf and root litter between the two forest types. Tree species have been shown to be different in the quantity and quality of litterfall and root inputs in various studies (Vog1 et al., 1991; Attiwill and Adams, 1993; Vesterdal et al., 20(02). Leaf litterfall and root inputs were not measured in this study, but it was found that the $\mathrm{C} / \mathrm{N}$ ratios for leal litter materials under NF were lower (23.5) than those under the $1 \mathrm{R}$ hoop pine plantation (42.5) (S. Ward, personal communication, 2003), which indicated better quality of leaf litter materials under NF. Lower soil pH under NF than under the $1 \mathrm{R}$ and $2 \mathrm{R}$ plantations may also contribute to the higher content of soil C observed under the NF. Beets et al. (20)(02) reported significant negative relationships between soil C and soil $\mathrm{pH}$, indicating that lower soil pH lead to the increased formation of $\mathrm{Al} / \mathrm{humic}$ acid complexes and, thus, enhanced the accumulation of soil $\mathrm{C}$. It has been suggested that low soil pH can decrease microbial biomass and activity (Blagodatskaya and Anderson, 1998) and might also lead to the accumulation of soil C (Beets et al., 20(12). However, in this study, the soil under NF had the lowest $\mathrm{pH}$, but the highest microbial biomass $\mathrm{C}$ (Fig. 3) and microbial activity as measured by $\mathrm{CO}_{2}$ respiration (data not shown). Also, using DNA techniques, it has been found that soil under NF has a higher microbial diversity than those under the plantations (J. He, personal communication, 2003). This indicates that there may be more diverse microbial communities and/ or specific microbial functional groups in soil under $\mathrm{NF}$ and their activities may contribute to the greater accumulation of soil $\mathrm{C}$. In addition, the disturbance during harvesting and site preparation might also decrease physical protection of soil organic matter for microbial attack (Lessa et al., 1996) and led to the lower levels of soil $\mathrm{C}$ under $1 \mathrm{R}$ and $2 \mathrm{R}$ hoop pine plantation compared with those under NF. But the nature and detail of such disturbance occurring approximately 50 yr ago are not available for appropriate comparisons.

The size and dynamics of soil labile $C$ can vary with tree species (Hu et al., 1997; Menyailo et al., 2002) and land-use type (Boyer and Groffman, 1996). Smolander and Kitunen (2002) compared adjacent soils under silver birch (Betula pendula Roth), Norway spruce (Picea abies (L.) Karst), and Scots pine (Pinus sylvestris L.) and found that concentrations of water dissolved organic $C$ were higher in the birch and spruce soils than in the pine soil. Results from the present study showed that conversion from NF to hoop pine plantations led to decreased labile $C$ pools extracted using cold water, $\mathrm{CaCl}_{2}$, or hot water (Table 2; Fig. 1 and 2 ), and bioavailC (Fig. 4). These labile ( pools were generally correlated with soil total $C(r=0.656-0.879, P<0.05)$. It has been suggested that labile (c.g., WSOC) may be mainly of microbial origin and could be derived from the leaching of forest floor materials (Gregorich et al., 2000; McGill et al., 1986; Qualls and Haines, 1991). The higher labile C pools in soil under the NF compared with the $1 \mathrm{R}$ plantation may be associated with the greater content of soil C and higher microbial activity under NF.

Signilicant correlations $(r=0.605-0.786, P<0.05)$ determined between the labile $C$ pools extracted with various solutions of different chemical and physical strengths (cold water, CaCls and hot water) indicated that they partly represented similar C pools in soil. However, the magnitude was very different among these 
pools. For example, the concentration of HWEOC was 20 to 30 times greater than that of WSOC (Table 2, Fig. 1). Hot water may not only extract soluble organic $\mathrm{C}$ in soil, but also part of the soil microbial components (Sparling et al., 1998). The highly significant linear relationship determined between HWEOC and bioavail-C in this study showed that HWEOC could be a good indicator of biologically labile organic C in soil (Fig. 7A), while the size of bioavail- $C$ was smaller than that of HWEOC by $243 \mathrm{mg} \mathrm{kg}^{-1}$ and approximately 9.2 to $32.1 \%$ of HWEOC was not biologically available. Some other researchers found a strong correlation between organic C extracted by hot water and mineralizable $\mathrm{C}$ and but also suggested some parts of soluble organic C were slowly decomposable (Davidson et al., 1987; Gregorich et al., 2003). In addition, it should be noted that the fulvic acid fraction of water-soluble organic $\mathrm{C}$ (WSOC-FA) was more sensitive to forest conversion compared with the humic acid fraction (WSOC-HA) (Table 2). However, the biological implication of this finding is not well understood.

Results from the ${ }^{13} \mathrm{C}$ CPMAS NMR spectroscopy showed that the relative intensities of different $\mathrm{C}$ functional groups in soils under different vegetation types were within the normal ranges reported (Mahieu et al., 1999), with the intensity of the alkyl C spectral region in soils at all three sites being the highest (Table 3, Fig. 5). This was consistent with the findings of Oades et al. (1988), in which the alkyl C region was predominant in three Australian soils studied. The significant relationship found between the $\mathrm{O}$-alkyl $\mathrm{C}$ region and the bioavail-C (Fig. 7B) showed that at least part of the O-alkyl C was biologically available, which was consistent with other studies (Novak et al., 1992; Guinto et al., 1999; Webster et al., 2000).

The conversion from NF to hoop pine plantations led to a change in the chemical composition of soil $\mathrm{C}$ with a higher intensity in the $\mathrm{O}$-alkyl $\mathrm{C}$ spectral region and lower intensity in the alkyl $\mathrm{C}$ spectral region in soil under NF than under the $1 \mathrm{R}$ plantation (Table 3, Fig. 5). Among the chemical components of the O-alkyl $\mathrm{C}$ region, the higher intensity obscrved in carbohydrate $C$ spectral region in soil under NF compared with the $1 \mathrm{R}$ plantation indicated that carbohydrate $\mathrm{C}$ was sensitive to the land-use change from natural forest to hoop pine plantation (Table 3, Fig. 5). The A/O-A ratio has been used to indicate the extent of decomposition of organic matter (Baldock and Preston, 1995). The lower A/O-A ratio in soil under $\mathrm{NF}$ than under the $1 \mathrm{R}$ plantation indicated that less accumulation of relative recalcitrant C components had occurred in the soil and the quality of soil organic $C$ was better under NF. This result may also show that litter materials from the hoop pine plantations may contain more recalcitrant components than those from NF. A number of studies have suggested that the nature of soil $\mathrm{C}$ is closely associated with vegetation type (Baldock and Preston, 1995; Condron and Newman, 1998; Golchin et al., 1997; Quideau et al., 2001). For example, Quideau et al. (2001) found that soil carbonyl $\mathrm{C}$ was dominant under oak, soil O-alkyl $\mathrm{C}$ under, and soil alkyl $\mathrm{C}$ under conifers. These effects have been attributed to different chemical composition of litter materials, soil environmental factors, soil organic C-mineral interactions, and the composition of microbial community and associated decomposition and humification processes under different vegetation types (Baldock et al., 1992; Beycr, 1995; Oades et al., 1988; Quideau et al., 2001; Schmidt et al., 2000); Trofymow et al., 1995; Webster et al., 2000).

There were significant negative relationships between $\mathrm{CHCl}_{3}$-released $\mathrm{C}$ and alkyl $\mathrm{C}$ (Fig. 6A) and between $\mathrm{CHCl}_{3}$-released $\mathrm{C}$ and the $\mathrm{A} / \mathrm{O}-\mathrm{A}$ ratio (Fig. 6B), which were consistent with other studies (Beycr, 1995; Webster et al., 2000). 'These results also showed that microbial degradation of alkyl $\mathrm{C}$ might be retarded in soil under the $1 \mathrm{R}$ plantation. Quideau et al. (2001) found that the prevalence of alkyl $\mathrm{C}$ in the fine silt fractions under coniferous species might be associated with low microbial activity and arise from the selective preservation of recalcitrant litter moieties (c.g., cutin, waxes etc.). The positive relationship determined between $\mathrm{CHCl}_{3}$-released $\mathrm{C}$ and $\mathrm{O}$-alkyl C (Fig. 6A) showed that higher microbial biomass (and activity) in soil under $\mathrm{NF}$ favored the production and/or accumulation of $\mathrm{O}$-alkyl C. It was believed that in this study more diverse microbial communities and wider associated synthetic pathways under NF played a key role in the differences observed in the chemical structure of soil $\mathrm{C}$ between $\mathrm{NF}$ and the $1 \mathrm{R}$ plantation. Yanagi et al. (20(02) also revealed that the resistance of soil humic acids to microbial degradation was related to differences in their chemical structure and was also microbial species dependent. The NF in this study was a mixture of different tree and shrub species with broad leaves and needles, and the quality of associated leaf litters (C/N ratio, see above) was assumed to be better compared with the hoop pine plantations. Therefore, differences in chemical composition of soil C observed between NF and the $1 \mathrm{R}$ plantation may be accounted for by a combination of factors including chemical composition of litter materials, microbial community structure, and organomineral interaction.

\section{Effects of Plantation Harvesting and Site Preparation on Soil Organic Carbon}

No significant differences in soil total $\mathrm{C}$ were observed between the $1 \mathrm{R}$ and $2 \mathrm{R}$ plantations, indicating that harvesting and site preparation of the hoop pine stands did not have significant impacts on soil total $C$, at least in the short term (2 yr alter harvesting). Johnson and Curtis $(2001)$ also found that tree harvesting had little or no effects on soil total $C$ content $15 \mathrm{yr}$ after harvesting. In addition, there were no significant differences in labilc soil organic $C$ pools, except in WSOC between the 1R and 2R plantations (Table 2, Fig. 1, 2, and 4). The WSOC was the most labile (C pool but least in magnitude compared with $\mathrm{CaCl}_{2}$ and $\mathrm{HWEOC}$ (Table 2, Fig. 1 and 2). The increased aggregate disruption and decreased physical protection of soil $\mathrm{C}$ by disturbance caused by harvesting and site preparation in soil under the $2 \mathrm{R}$ plantation may account for the lower 
WSOC compared with the $1 \mathrm{R}$ hoop pine plantation (Dai et al., 2001; Zinn et al., 2002). Results from the solidstate ${ }^{13} \mathrm{C}$ CPMAS NMR analysis showed that harvesting and site preparation significantly reduced signal intensity in the alkyl $\mathrm{C}$ spectral region (Table 3), leading to a decreased A/O-A ratio ('Table 3, Fig. 5). This is presumed to be due to less physical protection of soil organic $\mathrm{C}$ under the $2 \mathrm{R}$ plantation because of the disturbance and the higher soil microbial biomass and activity under the $2 \mathrm{R}$ than the $1 \mathrm{R}$ plantation (Fig. 3), which favored the degradation of soil alkyl C under $2 \mathrm{R}$ plantation. In addition, the signal intensity in the carboxyl C spectral region was higher in soil under the $2 \mathrm{R}$ plantation compared with the $1 \mathrm{R}$ plantation and NF (Table 3 ). This indicated that carboxyl $\mathrm{C}$ was sensitive to the disturbance caused by harvesting and site preparation (Lessa et al., 1996).

\section{CONCLUSIONS}

The conversion from NF to hoop pine plantations led to a reduction in soil total $\mathrm{C}$, labile $\mathrm{C}$ pools and the bioavailability of soil $\mathrm{C}$, and to the change in chemical composition of soil $\mathrm{C}$ with higher O-alkyl $\mathrm{C}$ and lower alkyl $\mathrm{C}$ under NF compared with the $1 \mathrm{R}$ plantation. These differenees in the quantity and quality of soil $\mathrm{C}$ between the NF and the $1 \mathrm{R}$ plantation may be attributed to a combination of factors including more diverse microbial communities, higher microbial activity and better quality of litter materials under the NF than the $1 \mathrm{R}$ plantation and site disturbance during the establishment of $1 \mathrm{R}$ plantation. Tree harvesting and site preparation in the $2 \mathrm{R}$ hoop pine plantation did not significantly affect soil total $\mathrm{C}$ and labile $\mathrm{C}$ pools (except the decrease in WSOC), but led to lower signal intensity in the alkyl C. spectral region, which decreased the $\mathrm{A} / \mathrm{O}-\mathrm{A}$ ratio in soil under the $2 \mathrm{R}$ plantation than under the $1 \mathrm{R}$ plantation. The decrease in WSOC and the increase in signal intensity of the alkyl $\mathrm{C}$ spectral region in soil under the $2 \mathrm{R}$ plantation than the $1 \mathrm{R}$ plantation may be partly attributed to the decreased physical protection of soil C caused by harvesting and site preparation and higher microbial biomass and activity under the $2 \mathrm{R}$ plantation. It is worthwhile to note that this is a case study and future studies are needed to further support these findings.

\section{ACKNOWLEDGMENTS}

Mr. Paul Keay and Mr. Jim I le are gratefully acknowledged for licld assistanee in soil sampling. We also thank Dr. Chris L. Beadle of the CRC/CSIRO Forestry and Forest Products, Australia, for his helpful comments on this manuscript.

\section{REFERENCES}

Altiwill, P.M., and M.^. Aclams. 1993. Tansley Review No. 50-Nutrient cycling in forests. Now Phytol. 124:561-582.

Baldock. J.A. and C.M. Presion. 1995. (hemistry of carbon deconposition processes in forests as revealed by solid-state carbon 13 nuclear magnetic resonance. pp. 89-117. In W.W. Mcliee and Kelly J. M. (ed.) Carbon forms and functions in forcst soils. SSSA, Madison, WI.

Baldock. J.A. J.M. Oades, A.G. Waters, X. Peng, A.M. Vassolo, and
M.A. Wilson. 1992. Aspects of the chemical structure of soil oreanic material as revealed by solid state ${ }^{1: C}$. NMR spectroscopy. Biogeochemistry $16: 1-42$.

Bects, P.N., G.R. Oliver, and P.W. Clinton. 2002. Soil carbon protection in podocarp/hardwood forest, and effects of conversion to pasture and exotic pine forest. Environ. Pollut. 116:63-73.

Beyer, L. 1995. Soil microbial hiomass and organic matter composition in soils under cultivation. Biol. Fertil. Soils 19:197-202.

Blagodatskaya, F.V., and T.-H. Anderson. 1998. Interactive effects of $\mathrm{pH}$ and substrate quality on the fungal-to-bacteria ratio and e $\mathrm{CO} 2$ of microbial communities in forest soils. Soil Biol. Biochem. 30:1269-1295.

Boycr, J.N., and P.M. Groflman. 1996. Bioavailability of watcr extractable organic carbon fractions in forest and agricultural soil profiles. Soil Biol. Biochem. 28:783-79).

Chen, C.R., L.M. Condron, M.R. Davis, and R.R. Sherlock. 2001. Effects of land-use changes from grassland to forest on soil organic sulfur and arylsulfatase activity in New Zealand. Aust. J. Soil Ros. 39:749-757.

Chen, C.R., L.M. Condron, M.R. Davis, and R.R. Sherlock. 2000 . Effects of afforestation on phosphorus and biological properies in a New Zealand grassland soil. Plant Soil 220:151163.

Chodak, M., B. L.udwig, P.K. Khanna, and F. Becsc. 20(2). Use of near infrared spectroscopy to determine biological and chemical characteristics of organic layers under spruee and beech stands. J. Plant Nutri. Soil Sci. 165:27-33.

Condron, L.M., and R.l. Newman. 1998. Chemical nature of soil organic matter under grassland and recently established forest. Eur. J. Soil Sci. 49:597-603.

Conte, P., A. Piccolo, B. van Lagen, P. Buurman, and M.A. Ilemminga. 2002. Elemental quantitation of natural organic matter by CPMAS ${ }^{1} \mathrm{C}$ NMR spectroscopy. Solid State NMR 21:158-170.

Dai, K.O., C.E. Johnson, and C.T. Driscoll. 2001. Organic matter chemistry and dynamies in efear-cut and unmanaged hardwood forest ecosystens. Biogeochomistry 54:51-83.

Davidson, F.A., L.F. Galloway, and M.K. Strand. 1987. Assessing available carbon: Comparison of technicjues across selected forest soils. Conmun. Soil Sei. Plant Anal. 18:45-64.

Davis, M.R. and L.M. Condron. 2002. Impacts of grassland afforestation on soil carbon in New Zealand: $\triangle$ review of parred site studies. Aust. J. Soil Res. 40:675-690).

Golchin, A.. P. Clarke, J.A. Baldock, T. Higashi, J.O. Skjemstad, and J.M. Oaldes. 1997. The ellects of vegetation and burning on the chemical composition of soil oreanic mater in a volcanic ash soil as shown by "C NMR spectroscopy. I. Whole soil and humic acid fraction. Geoderma 76:15,-174.

Gregorich, E.G., B.C. Liang, C.J. Drury, A.I. Mackenzic, and W.B. Mc(jill, 2000. Elucidation of the source and turnover of wates soluble and microbial bionass carbon in agricultural soils. Soil Biol. Biochem. 32:581-587.

Gregorich, L.G., M.H. Beare, U. Stoklas, and P. S1-Georges. 2003. Biodegradability of soluble organic matter in maise-cropped soils. Gcoderma 113:237-252.

Guinto, D.F., P.G. Salligna. Z.Il. Xu, A.P.N. Ilouse, and M.C.S. Perera. 1999. Soil nitrogen mineralization and organic matter composition revealed by C NMR spectroscopy under repeated prescribed burning in cucalypt forests of southeast Qucenstand. Aust. J. Soil Res. 37:123-135.

Howard, P.J.A., D.M.L. Howard. and L.E. Lowe. 1998. Elfects of tree species and soil physico-chemical conditions on the nature of soil organic matter. Soil Biol. Biochem. 30):285-297.

Hu. S., D.C. Coleman, C.R. Carroll, P.F. Ilendrix, and M.I I. Beare 1997. Labile soil carbon pools in subtropical forest and agricultural coosystems as influenced by management practices and vegetation types. Agric. Ecosyst. Lnviron. 65:69-78.

Johnson, D.W., and P.S. Curtis. 2001. Liffects of forest managemont on soil C and $N$ storage: Meta analysis. For, Feol. Manage. 140: $227-238$.

Kögel-Knabner, I. 2000. Analytical approaches for chatacterizing soil organic mat1er. Org. Geochem. 31:609).625.

Lessa, A.S.N., D.W Anderson, and B. Chatson. 1996. Cultivation ellects on the nature of organic matter in soil and water extracts using CP/MAS ${ }^{13} \mathrm{C}$ NMR spectroseopy. Plant Soil 184:207-217.

Magid, J., G. Cadisch, and K.F. (iiller. 2002. Short and mediun term 
plant litter decomposition in a tropical Ultisol clucidated by physi cal fractionation in a dual ${ }^{13} \mathrm{C}$. and ${ }^{14} \mathrm{C}$. isotope study. Soil Biol. Biochem. 34:1273-1281.

Mahicu, N., D.S. Powtson, and E.W. Randall. 1999. Statistical analysi of published carbon-13 CPMAS NMR spectra of soil organic matter. Soil Sci. Soc. Am. J. 63:307-319.

Mao, X.A., Z.H. Xu, R.S. L.uo, N.J. Mathers, Y.H. Zhang, and P.G. Salfigna. 2002. Nitrate in soil humic acids revealed by ${ }^{1+} \mathrm{N}$ nuclear magnetic resonance spectroscopy. Aust. J. Soil Res. 40:717-726.

Mathers, N.J., X.A. Mao, Z.H. Xu, P.G. Saffigna, S.J. Berners-Price, and M.C.S. Perera. 2000). Recent advances in the application of ${ }^{13} \mathrm{C}$ and ${ }^{15} \mathrm{~N}$ NMR spectroscopy to soil organic matter studies. Aust. J. Soil Res. 38:769-787.

Mathers, N.J. Z.II. Xu, S.J. Berners-Price, M.C.S. Perera, and P.G. Salfigna. 2002. Hydrolluoric acid pre-treatment for improving ' CPMAS NMR spectral quality of forest soils in south-cast Queensland, Australia. Aust. J. Soil Res. 40:655-674.

McGill, W.B., K.R. Camnon, J.A. Robertson, and F.I. Cook. 1986. Dynamics of soil microbial biomass and water-soluble organic $\mathrm{C}$ in Breton $\mathrm{L}$ after 50 years of cropping to two rotations. Cin. J. Soil Sci. 66:1-19.

Menyailo, O.V., B.A. Hungate, and W. Zech. 2002. Tree species mediated soil chemical changes in a Siberian artilicial afforestation experiment. Plant Soil 242:171-182

Nishiyama, M., Y. Sumikawa, G. Gang, and T. Marumoto. 2001. Relationship between microbial biomass and extractable organic carbon content in volcanic and non-volcanic ash soil. Appl. Soil Fcol. 17:183-187

Novak, J.M., P.M. Bertsch, and G.L, Mills. 1992. Carbon-13 nuclean magnetic resonance spectra of soil water-soluble organic carbon. J. Environ. Qual. 21:537-539.

Oades, J.M., A.G. Waters, A.M. Vassallo, M.A. Wilson, and G.P. Jones. 1988. Inlluence of management on the composition of organic matter in a red-brown carth as shown by ${ }^{13} \mathrm{C}$ nuclear magnetic resonance. Aust. J. Soil Res. 26:289-299.

Paul, K.I., P.J. Polglase, J.G. Nyakuengama, and P.K. Khanna. 2002. Change in soil carbon following afforestation. For. Ecol. Manage. 168:241-257.

Pinzari, F., A. Trinchera, A. Benedetti, and P. Sequi. 1999. Use of biochemical indices in the Mediterranean environment: comparison among soils under different forcst vegetation. J. Microbiol. Methods $36: 21-28$.

Preston, C.M. 1996. Application ol NMR to soil organic matter analysis: History and prospects. Soil Sci. 161:144-165.

Preston, C.M. 2001. Carbon-13-solid state NMR of soil organic mat ter-Using the technique effectively. Can. J. Soil Sci. 81:25.5-270.

Priha, O., and A. Smolander. 1999. Nitrogen transformations in soil under Pinus sylvestris, Picea abies and Betula pendula at two forest sites. Soil Biol. Biochem. 31:965-977.

Qualls, R.G., and B.L. Haines. 1991. Fluxes of dissolved organic nutricnts and humic substances in a deciduous forest. Eeology 72:254266.

Quideau, S.A., M.A. Anderson, R.C. Graham, O.A. Chadwick, and S.E. 'Trumbore. 2000. Soil organic matter processes: Characterization by ${ }^{13} \mathrm{C}$ NMR and ${ }^{14} \mathrm{C}$ measurements. For. Ecol. Manage. 138:19-27.

Quideau, S.A., O.A. Chadwick, A. Bencsi, R.C. Graham, and M.A. Anderson. 2001. A direci link between forest vegetation type and soil organic matter composition. (jeoderma 104:41-60.

Ross. D.J. and (G.P. Sparling. 1993. Comparison of methods to estimate microbial $\mathrm{C}$ and $\mathrm{N}$ in litter and soil under Pinas radiata on a coastal sand. Soil Biol. Biochem. 25:1591-1599.

Schmidt, M.W.I., II. Knicker, P.G. Hatcher, and I. Kögel-Knabner.
1997. Improvement of ${ }^{C}$ and ${ }^{15} \mathrm{~N}$ CPMAS NMR spectra of bulk soils, particle size fractions and organic material by treatment with $10 \%$ hydrofluoric acid. Liur. J. Soil Sci. 48.319 .328$.

Schmidt, M.W.I., II. Knicker, and I. Kögcl-Knabner. 2000). Organie matter accumulating in Aeh and Bh horizons of a Podzol-Chemical characterization in primary organo-mineral associations. Org. Geochem. 31:727-734.

Schnitzer, M. 2001. The in situ analysis of organic matter in soils. Can. J. Soil Sci. 81:249-254.

Schroth, G., S.A. D Angelo, W.G. Teixeira, D. Hatag, and R. Licherei. 2002. Conversion of secondary forest into agroforestry and monoculture plantations in Amazonia: consequences for biomass, litter and soil carbon stocks after 7 years. For. Ecol. Manage. 16.3: $131-150$.

Shiels A.B., J. Sanford, and L. Robert. 2001. Soil nutrient diflerences between two krummholz-form tree species and adjacent alpine tundra. Geoderma 102: 205-217.

Skjemstad, J.O., P. Clarke, J.A. Taylor, J.M. Oades, and R.II. Newman. 1994. The removal of magnetic materials from surface soils. $A$ solid state ${ }^{13}$ C CP/MAS NMR study. Aust. J. Soil Res. 32:121.5-1229.

Smith. C.K., O.F. de Assis, II.L. Ghol\%., and A. Baima. 2002. Soil carbon stocks after forest conversion to lree plantations in lowland Amazonia, Brazil. For. Ecol. Manage. 164:257-26.3.

Smolander, A., V. Kitunen, and E. Mälkönen. 2001. Dissolved soil organic nitrogen and carbon in a Norway spruce stand and an adjacent clear-cut. Biol. Iertil. Soils 33:19(0-196.

Smolander, A., and V. Kitunen. 2002. Soil microbial activities and characteristies of dissolved organic $\mathrm{C}$ and $\mathrm{N}$ in relation 10 tree species. Soil Biol. Biochem. 34:651-66(0).

Soil Survey Stalf. 1999. Soil taxonomy a basic system of soil classification for making and interpreting soil surveys. 2nd ed. USDA Soil Conservation Service, Washington, DC.

Sparling, C.P.. M. Vojvodić-vuković, and 1..A. Schipper. 1998. Hotwater soluble $C$ as simple measure of labile soil organic matter: The relationship with microbial biomass C. Soil Biol. Biochem. 30: $1469-1472$

Trofymow, J.A. C.M. Preston. and C.E. Preseott. 1995. Litter quality and its potential elfects on decay rates of matcrials from Canadian forests. Water Air Soil Pollut. 82:215-226.

Vance, E.D., P.C. Brookes, and D.S. Jenkinson. 1987. An extration method for measuring soil microbial biomass C. Soil Biol. Biochem. 19:70)3-707.

Vesterdal, L., E. Ritter, and P. Gundersen. 2002. Change in soil organie carbon following afforestation of former arable land. For. Ecol. Manage. 169:137-147.

Vogt, K.A., D.J. Vogl, and J. Bloomlickd. 1901. Input of organic matter to the soil by trec roots. P. 171--190. In B.L. MeMichael and II. Persson (ed.) Plant rools and their cnvironment-Proceedings of an ISRR symposium. 21-26. Aug. 1988. Uppsala, Sweden. Elsevier. Amsterdam.

Webster, E.A. J.A. Chudek, and D.W. Hopkins. 2000), Carbon transformations during decomposition of different eomponents of plant leaves in soil. Soil Biol. Biochen. 32:301-314.

Wilson, M.A. 1987. NMR technicues and applications in geochemistry and soil chemistry. P'erganon Press. Oxford. UK.

Yanagi, Y., H. Tamaki, H. Otsuka, and N. Fujitake. 2002. Comparison of decolorization by microorganisms of humic acids with different ${ }^{3} \mathrm{C}$ NMR properties. Soil Biol. Biochem. 34:729-731.

Zaceheo, P., C. Cabassi, G. Ricea, and I. Crippa. 2002. Decomposition of organic residues in soil: experimental technique and spectroscopic approach. Org. (reochem. 33:327-345.

Zinn. Y.L. D.V.S. Resck, and J.L. da Silva. 2002. Soil organic earbon as affected by afforestation with Eitcalyptus and l'inus in the (errrado region of Brazil. For. Ecol. Manage. 166:28.5-294. 